\title{
Studies on Antimicrobial and Immunomodulatory Effects of Hot Aqueous Extract of Acacia nilotica L. Leaves against Common Veterinary Pathogens
}

\author{
Arvind Kumar Sharma, ${ }_{1}^{1}$ Amit Kumar, ${ }^{1}$ Sharad Kumar Yadav, ${ }^{1}$ and Anu Rahal ${ }^{2}$ \\ ${ }^{1}$ Department of Veterinary Microbiology, College of Veterinary Sciences and Animal Husbandry, Uttar Pradesh Pandit Deen \\ Dayal Upadhyaya Pashu Chikitsa Vigyan Vishwavidyalaya Evam Go Anusandhan Sansthan (DUVASU), Mathura 281001, India \\ ${ }^{2}$ Department of Veterinary Pharmacology and Toxicology, College of Veterinary Sciences and Animal Husbandry, \\ Uttar Pradesh Pandit Deen Dayal Upadhyaya Pashu Chikitsa Vigyan Vishwavidyalaya Evam Go Anusandhan \\ Sansthan (DUVASU), Mathura 281001, India \\ Correspondence should be addressed to Amit Kumar; balyan74@gmail.com
}

Received 13 November 2013; Revised 11 February 2014; Accepted 20 February 2014; Published 7 April 2014

Academic Editor: Suresh Tikoo

Copyright (C) 2014 Arvind Kumar Sharma et al. This is an open access article distributed under the Creative Commons Attribution License, which permits unrestricted use, distribution, and reproduction in any medium, provided the original work is properly cited.

\begin{abstract}
Acacia nilotica is a plant species that is almost ubiquitously found in different parts of the world. Various preparations of it have been advocated in folk medicine for the treatment of tuberculosis, leprosy, smallpox, dysentery, cough, ophthalmia, toothache, skin cancer as astringent, antispasmodic, and aphrodisiac since immemorial times. The present study investigates the antibacterial, antifungal, antiviral, and immunomodulatory potential of hot aqueous extract (HAE) of Acacia nilotica leaves. On dry matter basis, the filtered HAE had a good extraction ratio (33.46\%) and was found to have carbohydrates, glycosides, phytosterols, phenolic compounds, saponins, and flavonoids as major constituents. HAE produced dose dependent zone of inhibition against Klebsiella pneumoniae, Pseudomonas aeruginosa, E. coli, Bacillus cereus, Staphylococcus aureus, and Streptococcus uberis and fungal pathogens Aspergillus niger and Aspergillus fumigates; however, no antiviral activity was recorded against IBR virus. HAE of A. nilotica revealed both proliferative and inhibitory effects on the rat splenocytes and IL-10 release depending on the dose. Detailed studies involving wide spectrum of bacterial, fungal, and viral species are required to prove or know the exact status of each constituents of the plant extract.
\end{abstract}

\section{Introduction}

The genus Acacia is the second largest in the family Leguminosae, with about 1350 species. It is distributed throughout tropical and warm temperate areas of the world, with the largest concentration of species in Australia (957 species), The Americas (185 species), Africa (144 species), and Asia (89 species) [1]. Out of these, Acacia nilotica is one of the species that has been effectively utilized in folk medicine for the treatment of tuberculosis, leprosy, smallpox, dysentery, cough, ophthalmia, toothache, skin cancer as astringent, antispasmodic, and aphrodisiac by rural population $[2,3]$. Acacia nilotica leaves are protein rich and highly digestible. Leaves of Acacia plants, in general, possess a significant level of antibacterial activity against a wide range of bacterial pathogens, although the extent of antibacterial activity varies depending upon the type of extract [4-8]. Various extracts in water, methanol, ethanol, n-hexane, Chloroform, and petroleum ether are reported with variable antibacterial activity against Gram-positive and Gram-negative bacteria [7-12], common fungal pathogens [13-17], and viruses [1821]. Different preparations of A. nilotica leave have been reported with different phytoconstituents $[7,22,23]$. These constituents of extracts also revealed variable potential for blood cells proliferation [24] and immunomodulation [2527]. However, a complete composite study on all the potential activities of aqueous extract of A. nilotica, the most commonly used extract in households, is lacking against common yet potential veterinary pathogens. Thus, the present study was planned to evaluate common phytochemical constituents 
of aqueous extract with antimicrobial activity against common pathogens of veterinary importance and its role in splenocyte stimulation to influence immune response and cytokine induction.

\section{Materials and Methods}

2.1. Collection and Processing of A. nilotica Leaves. The authenticated and verified plant leaves were included in the study. Procured leaves were washed with single glass distilled water and dried at $37^{\circ} \mathrm{C}$ in incubator. The dried plants samples were ground to prepare a coarse powder. The powdered samples were used for preparation of HAE using soxhlet apparatus [23].

2.1.1. Extracts Preparation. Triple glass distilled water was used as solvent for HAE preparation using Soxhlet apparatus as per previously described method [28].

2.1.2. Determination of Yields of Extract. The evaporated dried extracts (on dry weight basis) were calculated by the following equation [29]:

$$
\text { Yield }\left(\frac{\mathrm{g}}{100 \mathrm{~g} \text { of dry plant material }}\right)=\frac{\left(W_{1} \times 100\right)}{W_{2}} \text {, }
$$

where $W_{1}$ was the weight of the extract after the solvent evaporation and $W_{2}$ was the weight of the dry plant material loaded for extraction.

2.1.3. Phytochemical Studies. Qualitative phytochemical analysis of crude hot aqueous extract was carried out as per the standard methods $[30,31]$ to detect the presence or absence of different phytochemical constituents, namely, alkaloids, glycosides, flavonoids, resins, tannins, saponins, fixed oils, reducing sugars, proteins, and amino acids.

2.1.4. Disc Preparation. Blank sterile discs (Himedia, Mumbai, India) of $6 \mathrm{~mm}$ diameter were loaded with HAE of different concentrations $(1000 \mathrm{mg} / \mathrm{mL}, 500 \mathrm{mg} / \mathrm{mL}$ and $250 \mathrm{mg} / \mathrm{mL}$ ) to prepare discs containing $20 \mathrm{mg}, 10 \mathrm{mg}, 5 \mathrm{mg}$, $2.5 \mathrm{mg}$, and $1.25 \mathrm{mg}$ extracts. Discs impregnated with sterilized triple distilled water were taken as negative control. Discs were allowed to dry at $40^{\circ} \mathrm{C}$ for 30 minutes [23]. Dried discs were tested for their sterility on nutrient and Sabouraud Dextrose agar (SDA).

\subsection{Antimicrobial Activities}

2.2.1. Bacterial, Fungal, and Virus Isolates. Bacterial cultures of Staphylococcus aureus, Bacillus cereus, Streptococcus uberis, Escherichia coli, Pseudomonas aeruginosa, and Klebsiella pneumonia and fungal cultures of Candida albicans, Aspergillus niger, and Aspergillus fumigatus were obtained from the Department of Microbiology and Immunology, UP Pt. Deen Dayal Upadhyaya Pashu Chikitsa Vigyan Vishwavidyalaya Evam Go Anusandhan Sansthan (DUVASU), Mathura, to determine in vitro antibacterial and antifungal activity of HAE. Prior to use, the bacterial and fungal isolates were recharacterized on the basis of morphological, cultural, and biochemical characteristics as per standard methods [32]. For antiviral activity, Infectious Bovine Rhinotracheitis (IBR) virus was obtained from the Department of Epidemiology, UP Pt. Deen Dayal Upadhyaya Pashu Chikitsa Vigyan Vishwavidyalaya Evam Go Anusandhan Sansthan, (DUVASU), Mathura. Before its use, IBR virus was subcultured and characterized by cytopathic effect in Madin-Darby Bovine Kidney (MDBK) cell line.

2.2.2. In Vitro Study of Antibacterial Susceptibility. Bacterial cell concentration of the bacterial cultures was determined on Muller Hinton Agar [HiMedia, Mumbai] by Spread Plate Method and colony forming unit per $\mathrm{mL}(\mathrm{CFU} / \mathrm{mL})$ were calculated by multiplying the number of colonies counted with respective dilution factor [33]. Antibacterial activity was carried out by disc diffusion method as per standard procedure [34]. Standard discs of antibiotic Tetracycline $(30 \mu \mathrm{g})$ and Amikacin $(30 \mu \mathrm{g})$ [Hi Media, Mumbai] were used as positive control for Gram-positive and Gram-negative bacteria, respectively.

2.2.3. In Vitro Antifungal Effect. The concentration of CFU of fungus was determined as per the method used for bacterial count except for the use of Sabouraud's Dextrose Agar (SDA) [HiMedia, Mumbai] in place of Muller Hinton Agar. In vitro study of antifungal susceptibility of plant extract was performed by standard disc diffusion method [34]. Standard antimycotic discs of Fluconazole (10 $\mu \mathrm{g})$ [Hi Media, Mumbai] were used as positive control for fungal agents.

2.2.4. In Vitro Antiviral Effect against IBR Virus. MDBK cell lines were obtained from the Department of Epidemiology, UP Pt. Deen Dayal Upadhyaya Pashu Chikitsa Vigyan Vishwavidyalaya Evam Go Anusandhan Sansthan, (DUVASU) Mathura. These were maintained at $37^{\circ} \mathrm{C}, 5 \% \mathrm{CO}_{2}$, and $80 \%$ relative humidity using Dulbecco's Modified Eagle's Medium (DMEM) growth medium supplemented with 10\% inactivated fetal calf serum, antibiotic antimycotic solution, sodium pyruvate, and sodium bicarbonate [35] to study the antiviral effect of HAE. To assess the antiviral effect the cellular toxicity of plant extract on MDBK cell line was carried by MTT \{3-(4,5-Dimethylthiazolyl)-2,5-diphenyl tetrazolium bromide $\}$ dye method [36] in 96-well cell culture plates. The concentration at which there was no reduction of viable cells was considered as maximum nontoxic dose (MNTD) of the extract [37]. The concentrations of aqueous extract lower than MNTD were screened for antiviral property against $\mathrm{TCID}_{50}$ virus challenge dose of IBR virus in MDBK cell lines. The antiviral effect was determined by cytopathic inhibition effect in MDBK cell lines and reduction in virus induced cytotoxicity was measured by using MTT dye uptake method [36] in the form of optical densities (O.D) [37]. The virus suspension and dilution medium without plant extract were also used as the virus control and cell control, respectively. Cell viability was evaluated by adding $10 \mu \mathrm{L}$ MTT dye $(5 \mathrm{mg} / \mathrm{mL})$ and then extracting the dye with 
TABLE 1: In vitro antibacterial effects.

\begin{tabular}{|c|c|c|c|c|c|}
\hline \multirow{2}{*}{ S. no. } & \multirow{2}{*}{ Name of bacteria } & \multirow{2}{*}{ Quantity of extract (mg/disc) } & \multicolumn{3}{|c|}{ Zone of inhibition (mm) after } \\
\hline & & & $24 \mathrm{hrs}$ & $36 \mathrm{hrs}$ & $48 \mathrm{hrs}$ \\
\hline \multirow{6}{*}{1} & \multirow{5}{*}{ Staphylococcus aureus } & 1.25 & 9 & 8 & 8 \\
\hline & & 2.5 & 10 & 9 & 9 \\
\hline & & 5 & 17 & 15 & 15 \\
\hline & & 10 & 20 & 19 & 19 \\
\hline & & 20 & 20 & 20 & 20 \\
\hline & Positive control & Tetracycline $(30 \mu \mathrm{g})$ & 30 & 30 & 30 \\
\hline \multirow{6}{*}{2} & \multirow{5}{*}{ Bacillus cereus } & 1.25 & 8 & 8 & 7 \\
\hline & & 2.5 & 12 & 10 & 9 \\
\hline & & 5 & 15 & 15 & 14 \\
\hline & & 10 & 18 & 17 & 17 \\
\hline & & 20 & 19 & 19 & 18 \\
\hline & Positive control & Tetracycline $(30 \mu \mathrm{g})$ & 23 & 23 & 23 \\
\hline \multirow{6}{*}{3} & \multirow{5}{*}{ Streptococcus uberis } & 1.25 & 9 & 9 & 9 \\
\hline & & 2.5 & 12 & 12 & 12 \\
\hline & & 5 & 16 & 16 & 16 \\
\hline & & 10 & 19 & 19 & 18 \\
\hline & & 20 & 22 & 22 & 22 \\
\hline & Positive control & Tetracycline $(30 \mu \mathrm{g})$ & 27 & 27 & 27 \\
\hline \multirow{6}{*}{4} & \multirow{5}{*}{ Escherichia coli } & 1.25 & 0 & 0 & 0 \\
\hline & & 2.5 & 8 & 8 & 7 \\
\hline & & 5 & 9 & 8 & 8 \\
\hline & & 10 & 11 & 10 & 10 \\
\hline & & 20 & 15 & 14 & 14 \\
\hline & Positive control & Amikacin $(30 \mu \mathrm{g})$ & 24 & 24 & 24 \\
\hline \multirow{6}{*}{5} & \multirow{5}{*}{ Pseudomonas aeruginosa } & 1.25 & 8 & 8 & 7 \\
\hline & & 2.5 & 10 & 9 & 8 \\
\hline & & 5 & 13 & 12 & 12 \\
\hline & & 10 & 15 & 13 & 13 \\
\hline & & 20 & 15 & 13 & 12 \\
\hline & Positive control & Amikacin $(30 \mu \mathrm{g})$ & 18 & 18 & 18 \\
\hline \multirow{6}{*}{6} & \multirow{5}{*}{ Klebsiella pneumoniae } & 1.25 & 9 & 9 & 8 \\
\hline & & 2.5 & 10 & 9 & 8 \\
\hline & & 5 & 13 & 12 & 12 \\
\hline & & 10 & 13 & 13 & 13 \\
\hline & & 20 & 13 & 13 & 13 \\
\hline & Positive control & Amikacin $(30 \mu \mathrm{g})$ & 25 & 25 & 25 \\
\hline 7 & Negative control & 0 & - & - & - \\
\hline
\end{tabular}

DMSO and measuring optical density (O.D.) at $560 \mathrm{~nm}-$ $670 \mathrm{~nm}$ as described previously. The percentage protection was calculated by the following formula:

$$
\frac{(\mathrm{ODt}) v-(\mathrm{ODc}) v}{(\mathrm{ODc}) m-(\mathrm{ODc}) v} \times 100 \text {, }
$$

where $(\mathrm{ODt}) v,(\mathrm{ODc}) v$, and $(\mathrm{ODc}) m$ correspond to absorbance in virus infected cells with plant extracts, virus infected cells without plant extracts, and cells without virus and plant extract, respectively $[35,37]$.

\subsection{Immunomodulatory Activities}

2.3.1. Experimental Animals. Wistar Albino Rats (Av wt$120 \mathrm{gm}$ ) were procured from the Department of Lab Animal Resource (LAR) of IVRI, Izatnagar, UP. The spleen cells were collected aseptically from the rats and used for spleenocyte proliferation and cytokine IL-10 analysis [35].

2.3.2. In Vitro Effect on Splenocytes Proliferation/Inhibition. The effect of HAE on splenocyte proliferation was evaluated 
TABLE 2: In vitro antifungal effects.

\begin{tabular}{|c|c|c|c|c|c|}
\hline \multirow{2}{*}{ S. no. } & \multirow{2}{*}{ Name of fungus } & \multirow{2}{*}{ Quantity of extract (mg/disc) } & \multicolumn{3}{|c|}{ Zone of inhibition $(\mathrm{mm})$ after } \\
\hline & & & $24 \mathrm{hrs}$ & $36 \mathrm{hrs}$ & $48 \mathrm{hrs}$ \\
\hline \multirow{5}{*}{1} & \multirow{5}{*}{ Candida albicans } & 2.5 & - & - & - \\
\hline & & 5 & - & - & - \\
\hline & & 10 & 10 & - & - \\
\hline & & 20 & 11 & - & - \\
\hline & & Fluconazole $(10 \mu \mathrm{g})$ & 28 & 28 & 28 \\
\hline \multirow{5}{*}{2} & \multirow{5}{*}{ Aspergillus niger } & 2.5 & - & - & - \\
\hline & & 5 & 8 & - & - \\
\hline & & 10 & 8 & 8 & 7 \\
\hline & & 20 & 12 & 11 & 11 \\
\hline & & Fluconazole $(10 \mu \mathrm{g})$ & 21 & 21 & 21 \\
\hline \multirow{5}{*}{3} & \multirow{5}{*}{ Aspergillus fumigatus } & 2.5 & - & - & - \\
\hline & & 5 & 8 & - & - \\
\hline & & 10 & 9 & 8 & 8 \\
\hline & & 20 & 13 & 13 & 12 \\
\hline & & Fluconazole $(10 \mu \mathrm{g})$ & 23 & 23 & 23 \\
\hline 4 & Negative control & 0 & - & - & - \\
\hline
\end{tabular}

with wells containing only spleen cells as negative control and wells containing spleen cells with Con-A as positive control [35]. After incubation, $20 \mu \mathrm{L}$ of MTT solution ( $5 \mathrm{mg} / \mathrm{mL}$ ) was added in each well for formazione crystal formation. The plate was reincubated at $37^{\circ} \mathrm{C}$ for $4 \mathrm{hrs}$ in $\mathrm{CO}_{2}$ incubator containing $5 \% \mathrm{CO}_{2}$ and $80 \%$ relative humidity. After incubation, supernatant was removed. The plate was air dried and $100 \mu \mathrm{L}$ of DMSO was added to dissolve the formazione crystals. O.D was taken at dual wavelength $560-670 \mathrm{~nm}$ by ELISA reader [35]. Mean values were calculated in comparison to control and taken positive if ratio was of significant difference [38].

\section{In Vitro Effect on IL-10 Cytokine Induction}

Splenocytes were prepared as prescribed for splenocyte proliferation assay and cultured in absence and presence of Con-A $(5 \mathrm{mg} / \mathrm{mL})$ along with $0.45 \mu \mathrm{m}$ membrane filtered HAE of plants $(31.25,62.5,125,250$, and $500 \mu \mathrm{g} / \mathrm{mL}$, extract) in the cell culture plate [39]. Procedure followed for IL-10 assay was similar to that for splenocytes proliferation assay. However, the spleen cells were incubated for $48 \mathrm{hrs}$ and then supernatant was collected for the detection of IL-10 cytokine. The quantitation of IL-10 cytokine in spleen culture supernatant was done according to the protocol supplied in the kit by BIOSOURCE (USA).

\section{Results}

4.1. Percentage Yield. On dry matter basis, the filtered HAE of Acacia nilotica leaves was $33.46 \%$ of the total dry weight of the leaves.

4.2. Phytochemical Studies. Phytochemical studies of HAE revealed the presence of carbohydrates, glycosides, phytosterols, phenolic compounds, saponins, and flavonoids as major constituents.

4.3. In Vitro Antibacterial Effects. All the bacterial pathogens revealed concentration dependent sensitivity against HAE. HAE was more effective against Gram-positive bacteria in comparison to Gram-negative bacteria (Table 1).

4.4. In Vitro Antifungal Effects. All the fungal pathogens revealed concentration dependant sensitivity against higher concentrations of HAE. The discs with 2.5 and $5 \mathrm{mg}$ concentration of HAE revealed no inhibition or the inhibition of the growth for initial few hours (Table 2).

\subsection{In Vitro Antiviral Activity against IBR Virus}

4.5.1. MNTD Determination in MDBK Cell Line. On the basis of observation of cytotoxic effect (vacuole formation and detachment of cells) in MDBK cells and absorbance, $1.25 \mathrm{mg} / \mathrm{mL}$ conc. of aqueous extract was determined as nontoxic dose of HAE. For further investigation, 1.25, 0.625, and $0.3125 \mathrm{mg} / \mathrm{mL}$ were taken to study the antiviral activity of $\mathrm{HAE}$ of $A$. nilotica leaves against IBR virus (Figures 1 and 6).

4.5.2. TCID $_{50}$ for IBR Virus. The number of viable cells after virus challenge was assessed by using MTT dye uptake assay and the virus dilution required to cause $50 \%$ cell death was calculated from dose response curve and virus was expressed as $\mathrm{TCID}_{50}\left(50 \%\right.$ tissue culture infective dose). $\mathrm{TCID}_{50}$ of IBR virus was determined at $10^{-1}$ virus dilution level (Figure 2).

4.5.3. Antiviral Effect against IBR Virus. HAE of A. nilotica leaves showed no antiviral property against IBR, showing no protection to the cell line against the virus (Figure 3). 


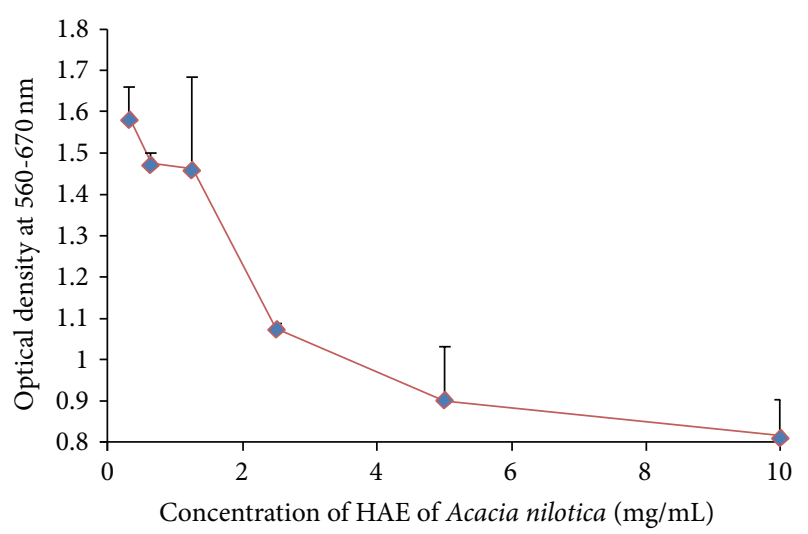

FIGURE 1: MNTD of HAE of Acacia nilotica leaves in MDBK cell line.

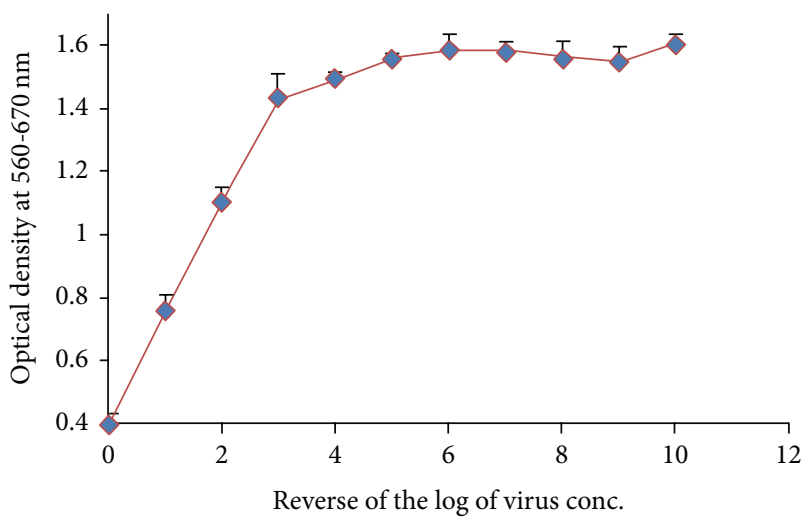

FIGURE 2: TCID $_{50}$ for Infectious Bovine Rhinotracheitis (IBR) virus.

4.6. In Vitro Effect on Splenocytes Proliferation/Inhibition. HAE of $A$. nilotica leaves had a proliferative as well as inhibitory effect on splenocytes. In comparison to negative control, 18.27, 28.36, 21.63, and 9.61\% increase in the proliferation of spleen cells were reported at the dose rate of $31.25,62.5,125$, and $250 \mu \mathrm{g} / \mathrm{mL}$ of HAE, respectively, whereas $45.67 \%$ inhibition was reported at dose rate of $500 \mu \mathrm{g} / \mathrm{mL}$ HAE of A. nilotica. In comparison to positive control, spleen cells with HAE of Acacia nilotica leaves in presence of ConA exhibited $11.17 \%$ and $13.18 \%$ increase in proliferation when splenocyte culture was treated with 31.25 and $62.5 \mu \mathrm{g} / \mathrm{mL}$ of HAE of $A$. nilotica, respectively. However, 22.33, 36.72, and $70.22 \%$ inhibition were observed when splenocyte culture treated with 125, 250, and $500 \mu \mathrm{g} / \mathrm{mL} \mathrm{HAE}$ of $A$. nilotica with Con-A, respectively (Figures 4 and 7).

4.7. In Vitro Effect on Induction of IL-10 Cytokine. Splenocytes treated with HAE in vitro revealed 24.78, 6.21, 6.69, 8.15, and $11.86 \%$ reduction in the IL-10 secretion at dose rate of $31.25,62.5,125,250$, and $500 \mu \mathrm{g} / \mathrm{mL}$ HAE of $A$. nilotica leaves, respectively, compared with negative control (only spleen cells). The minimum inhibition of cytokine secretion (6.21\%) was observed with $62.5 \mu \mathrm{g} / \mathrm{mL}$ HAE in absence of Con-A (Figure 5).

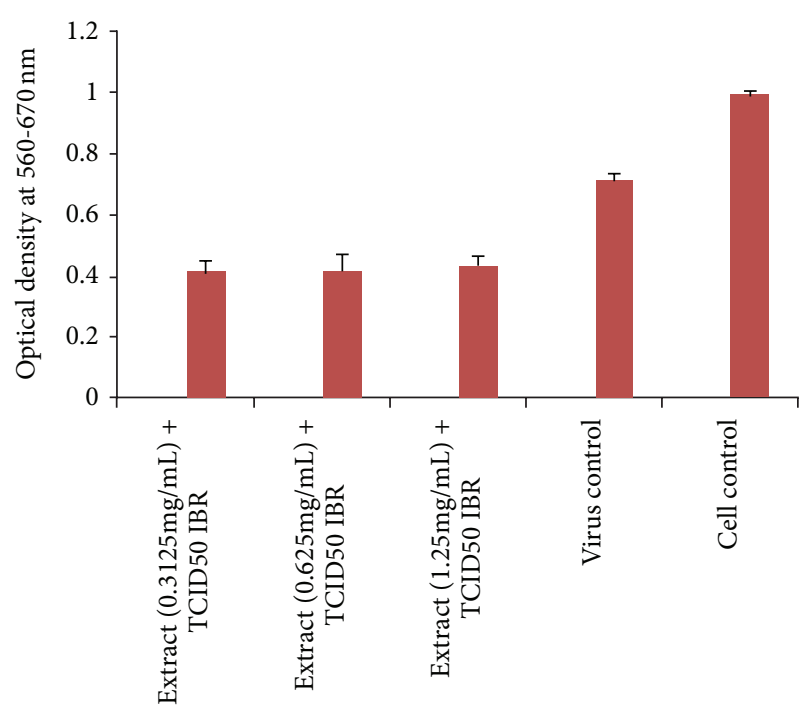

FIgure 3: Antiviral effect of HAE of Acacia nilotica leaves against IBR virus.

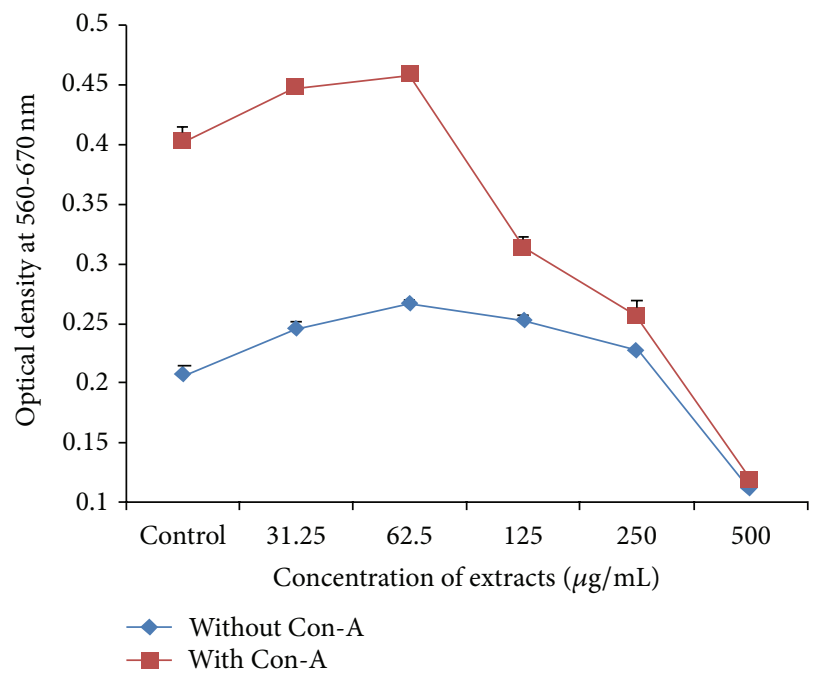

FIgURE 4: In vitro effect of HAE of Acacia nilotica leaves on Splenocyte proliferation in Wistar albino rats.

Splenocytes treated with HAE and Con-A was compared with positive control (spleen cells + Con-A) and it was found that IL-10 secretion was reduced by 13.85, 2.42, 6.59, 10.78 , and $21.09 \%$ when treated with $31.25,62.5,125,250$, and $500 \mu \mathrm{g} / \mathrm{mL}$ HAE, respectively. The minimum reduction $2.42 \%$ was observed with $62.5 \mu \mathrm{g} / \mathrm{mL}$ of HAE in presence of Con-A (Figure 5).

\section{Discussion}

A. nilotica is commonly located in Indian subcontinent [1] and is commonly used in folk medicine [40]. In traditional medicine, its role is well established [41]. However, in the era of increasing drug resistance to modern medicine in bacterial pathogens [42-44], it is to be validated scientifically. 


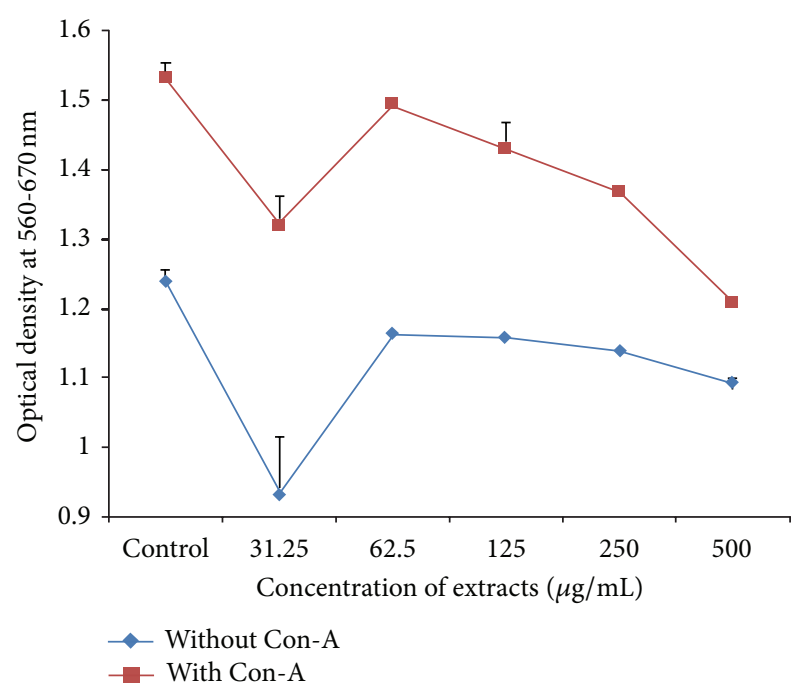

FIgURE 5: In vitro effect of HAE of Acacia nilotica leaves on Cytokine IL-10 induction.

Out of the numerous traditional therapeutic practices, the preparation of hot aqueous extract is the most common household means of herbal administration $[33,40]$. Therefore, the antimicrobial potential along with immunomodulatory effects of hot aqueous extract of $A$. nilotica leaves was investigated in the present study.

The high yield of the plant leaves extract (33.46\%) also supports its use and availability in folk medicine. The phytochemicals like tannins, flavonoids, phenols, and alkaloids are an important reflection of the pharmacological activities of a plant. The phytochemistry of the extract revealed the presence of carbohydrates, glycosides, phytosterols, phenolic compounds, saponins, and flavonoids as major constituents; the efficacy of these compounds is already well established for antimicrobial activities [8]. These findings are in agreement with earlier findings of phytoconstituents of different extracts of Acacia nilotica, namely, aqueous extract [22], methanolic, and ethanolic extracts $[7,23]$.

The HAE produced dose dependent zone of inhibition of variable size even after the incubation of 48 hours against both Gram-positive and Gram-negative bacteria (Table 1). These findings are in the concurrence with the earlier findings that reported better efficacy of Acacia nilotica extracts against Gram-positive cocci than Gram-negative bacilli [8]. The superior inhibition of bacterial growth against Gram-positive bacteria in comparison to Gram-negative bacteria might be because of the difference in cell wall composition of the bacteria [42]. Among Gram-negative bacteria, Klebsiella pneumoniae showed a little resistance to inhibition, perhaps due to the presence of a capsule [22]. The sensitivity of Grampositive bacteria was in support to the use of HAE extracts in skin ailments and conditions like mastitis [45]. Similar to our findings, E. coli has been earlier found sensitive to hot aqueous, ethanolic, and methanolic extracts of Acacia nilotica $[8,9,12,14]$. However, the alcoholic extracts are reported to have a better antibacterial activity against different bacterial pathogens with significant inhibition of growth as compared to the aqueous extracts $[10,15]$.

Other than the bacterial pathogens, mycotic pathogens are always a clinical challenge to veterinarian and are very difficult to control [46]. The fungal manifestations are generally chronic in nature. Although an exhaustive range of antifungal drugs are available, the treatment becomes uneconomical particularly in the large animals due to large dose size. Therefore, to find out a suitable plant extract with antifungal activity was one of the key aims of the study. In this regard, HAE of Acacia nilotica plant leaves was tested against most common veterinary fungal pathogens, namely, Candida albicans, Aspergillus fumigatus, and Aspergillus niger (Table 2). The HAE showed good antifungal activity against all the fungal pathogens at higher concentration (Table 2). The inhibition was better against Aspergillus fumigatus and Aspergillus niger and was comparable to fluconazole, the reference antifungal drug. Our findings are also in agreement to the earlier findings against eight species of Aspergillus and other fungal pathogens $[15-17,47]$. In contrast to our findings, some earlier reports have claimed absence of antifungal activity in HAE and other extracts of these plant parts $[13,14,48]$. This dissimilarity might be due to the difference in the collection season of plant material, extraction procedures, or geographical variations. The activity of HAE of A. nilotica leaves against $C$. albicans was only with higher concentration and only for 24 hours, while ethanolic extract of A. nilotica leaves were reported to be very effective [11]. This variation is commonly observed with the change of type of extract as phytoconstituents and their concentrations may vary significantly [8].

The severity of viral diseases and ability of virus to survive intracellularly pose a great challenge that is further aggravated by the nonavailability of specific antiviral chemical agents against veterinary pathogens [37]. Thus, the evaluation of antiviral effect of HAE of A. nilotica leaves was also attempted. The findings of the present study revealed no antiviral effect of HAE against IBR virus (Figure 3). There are no reports available on the antiviral activity of HAE of $A$. nilotica against IBR virus in the literature. However, variable antiviral activity of different extracts of different species of plant acacia have been reported, namely, Acacia nilotica (bark and pods) inhibitory effects against HIV-1 PR. [18]; Acacia gummifera inhibiting Sindbis virus [19]; Acacia arabica. var. indica against peste des petits ruminants virus (PPRV) [49]; Acacia arabica (babul) against Goat pox virus (GTPV) replication [21]; and Acacia nilotica (fruits) with mild virucidal to high activity against replication of Newcastle Disease virus and Fowl pox viruses [19, 21].

HAE of plant leaves revealed both proliferative and inhibitory effects on the splenocytes to be depending on the concentration of the extract (Figures 4 and 7). The proliferation of splenocyte occurred in dose dependent manner in the range of $9.61 \%$ to the $28.36 \%$. These observations are in agreement with the in vitro findings of stimulation of rat pleural polymorphonuclear leukocytes (PMNs) [24] and proliferation of splenocyte [26]. Thus, the lower concentrations of the HAE of plants could be used to improve immune response or to combat the microorganisms causing immune-suppression 

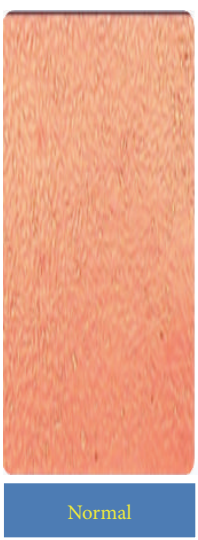
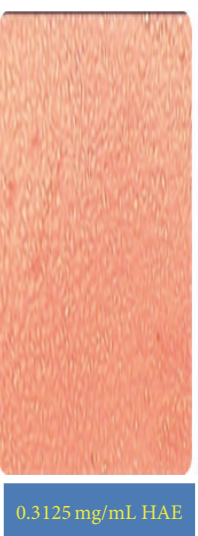

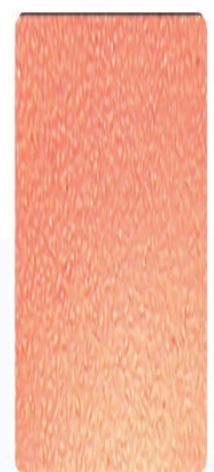

$0.625 \mathrm{mg} / \mathrm{mL}$ HAE
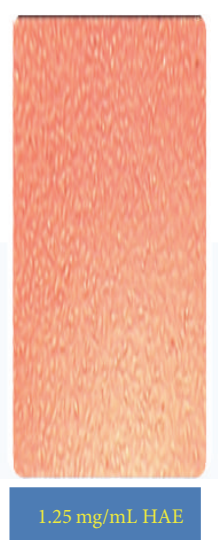
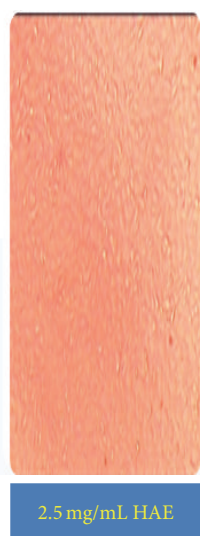
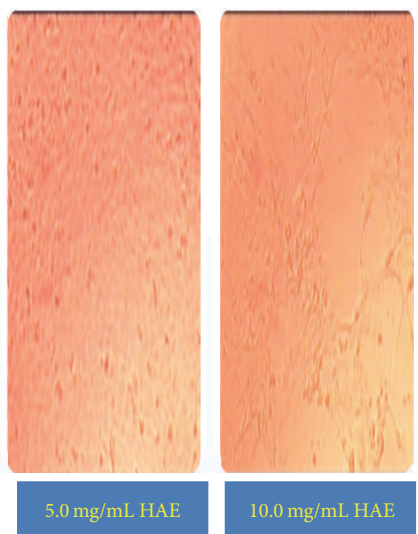

FIGURE 6: MNTD assessment with different concentrations of HAE of A. nilotica leaves in MDBK cell line, 10X.
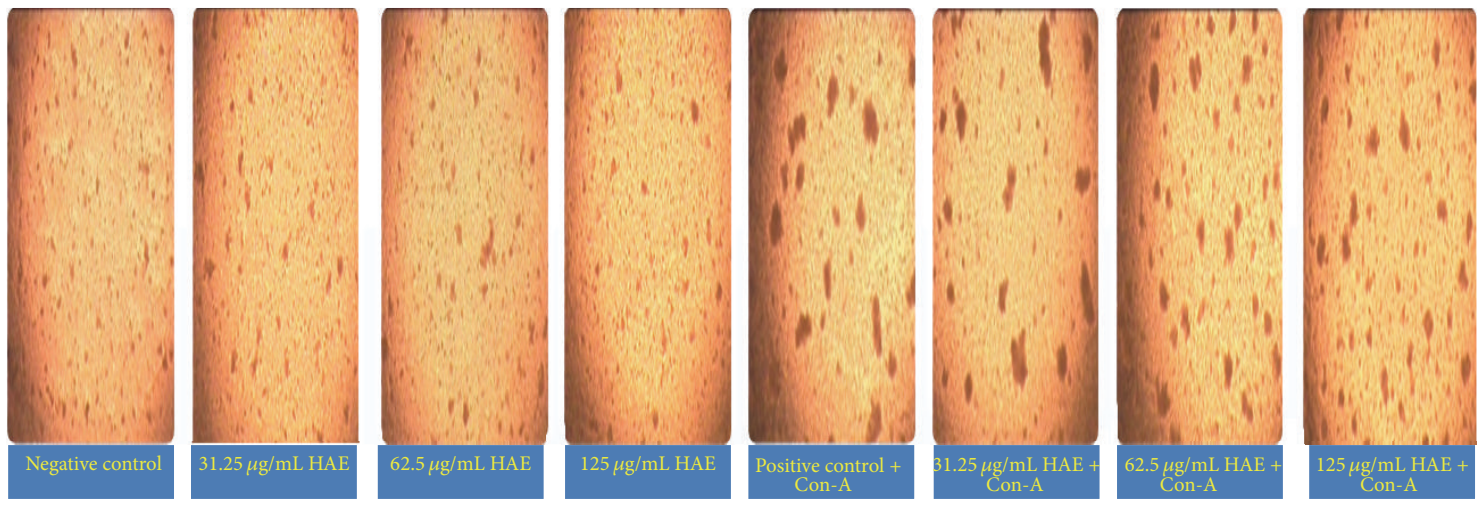

FIGURE 7: In vitro assessment of splenocyte proliferation with different concentrations of HAE of $A$. nilotica leaves on Wistar albino rat spleen cells, 10x.

as increase in the proliferation of splenocyte appeared to be an indicative of cellular immune response [50]. Moreover, oral feeding of Acacia catechu extract in mice produced a significant increase in the serum immunoglobulin levels, increase in the haemagglutination titre values, and decreased the mortality ratio in mice, suggesting its effect on the humoral arm of the immune system [27]. The inhibition of splenocytes proliferation observed at higher concentration of HAE (Figures 4 and 7) might be due to the accumulation of toxic constituents of plant extract which might be causing cytotoxic effects and ultimately inhibiting the cell proliferation [26]. The supernatants of splenocytes exposed to different concentrations of extract were assessed for the concentration of IL-10, an anti-inflammatory interleukin that plays important role in control of inflammatory process $[40,51]$. The HAE of Acacia nilotica downregulated the IL10 release from spleen cells in lower doses and maximum inhibition was $24.78 \%$. Then inhibition was reduced with increase in HAE concentration, however further higher doses downregulated IL-10 release. Hence, dose dependent upregulation is observed in certain concentration which is again downregulated with increase in extract concentration (Figure 5). Thus, proliferation of splenocytes and upregulation of IL-10 can be observed for an optimum concentration of extract. No literature is available on IL-10 regulation regarding this plant. Further, there are scanty reports available on the use of medicinal plants or the extracts of plant parts on the regulation of IL-10 as Fu-ling Chinese herb produced upregulation of IL-10 in murine spleen cell [52] and Phyllanthus amarus inhibited induction of interleukin (IL)$1 \beta$, IL-10, and interferon- $\gamma$ in human whole blood [53]. Since cytokines regulate certain important biological functions such as cell growth, cell activation, immunity, inflammation, tissue repair, fibrosis, morphogenesis, and chemotaxis, thus the up- or downregulation of cytokines directly affect the body defense mechanism.

\section{Conclusions}

The study had tried to cover almost all the aspects of microbial pathogenesis and revealed that HAE of Acacia nilotica leaves had different effects upon bacteria, virus, and fungi with dose dependent variation in immunomodulatory and anti-inflammatory activities. HAE of Acacia nilotica leaves showed excellent antibacterial and antifungal activities with comparatively lesser antiviral and immunomodulatory activities. HAE of Acacia nilotica leaves had various active components that might have a role in variation in overall activities; therefore, further detailed studies involving wide 
spectrum of bacterial, fungal, and viral species are required to prove the exact statics of each constituent of the plant extract. However, study had shown an important level of the valuable effects of Acacia nilotica leaves.

\section{Conflict of Interests}

The authors of this paper do not have a direct financial relation that might lead to a conflict of interests for any of them.

\section{Acknowledgments}

The authors are thankful to the Dean of College of Veterinary Sciences and Vice Chancellor of UP Pt. Deen Dayal Upadhyaya Veterinary University \& Gau Anusandhan Sansthan (DUVASU), Mathura, for providing the requisite facilities and support to carry out this investigation.

\section{References}

[1] B. R. Maslin, J. T. Miller, and D. S. Seigler, "Overview of the generic status of Acacia (Leguminosae: Mimosoideae)," Australian Systematic Botany, vol. 16, no. 1, pp. 1-18, 2003.

[2] J. A. Duke, Medicinal Plants of the Bible, Trado-Medic Book, Owerri, NY, USA, 1983.

[3] B. P. van Wky and B. E. van Wky, PhoTographic Guide to Trees of Southern Africa, Briza Publications, Pretoria, South Africa, 2000.

[4] T. R. New, A Biology of Acacias, Oxford University Press, New York, NY, USA, 1984.

[5] A. Kumar, A. Rahal, and A. K. Verma, "In vitro antibacterial activity of hot aqueous extract (HAE) of Ocimum sanctum (Tulsi) leaves," Indian Journal of Veterinary Medicine, vol. 31, no. 2, pp. 96-97, 2011.

[6] H. Upadhyay, A. Kumar, M. K. Gupta, A. Sharma, and A. Rahal, "Validation of medicinal values of traditionally used Sonchus asper (Prickly Sow Thistle) Leaves for the treatment of skin ailments," Advancement in Medicinal Plant Research, vol. 1, no. 3, pp. 29-35, 2013.

[7] G. O. Solomon-Wisdom and G. A. Shittu, "In vitro antimicrobial and phytochemical activities of Acacia nilotica leaf extract," Journal of Medicinal Plant Research, vol. 4, no. 12, pp. 1232-1234, 2010.

[8] N. K. Mustafa, M. O. M. Tanira, F. K. Dar, and H. Nsanze, "Antimicrobial activity of Acacia nilotica subspp. nilotica fruit extracts," Pharmacy and Pharmacology Communications, vol. 5, no. 9, pp. 583-586, 1999.

[9] M. E. Arias, J. D. Gomez, N. M. Cudmani, M. A. Vattuone, and M. I. Isla, "Antibacterial activity of ethanolic and aqueous extracts of Acacia aroma Gill. ex Hook et Arn," Life Sciences, vol. 75, no. 2, pp. 191-202, 2004.

[10] A. M. H. Ali and S. O. Yagoub, "Antimicrobial activity of Acacia nilotica extracts against some bacteria isolated from clinical specimen," Research Journal of Medicinal Plants, vol. 1, no. 1, pp. 25-28, 2007.

[11] R. Khan, B. Islam, M. Akram et al., "Antimicrobial activity of five herbal extracts against Multi Drug Resistant (MDR) strains of bacteria and fungus of clinical origin," Molecules, vol. 14, no. 2, pp. 586-597, 2009.
[12] J. D. Patel, D. K. Patel, A. K. Shrivastava, and V. Kumar, "Evaluation of some medicinal plants used in traditional wound healing preparations for antibacterial property against some pathogenic bacteria," Journal of Clinical Immunology and Immunopathology Research, vol. 1, no. 1, pp. 7-12, 2009.

[13] O. J. M. Hamza, C. J. P. van den Bout-van den Beukel, M. I. N. Matee et al., "Antifungal activity of some Tanzanian plants used traditionally for the treatment of fungal infections," Journal of Ethnopharmacology, vol. 108, no. 1, pp. 124-132, 2006.

[14] R. Dabur, A. Gupta, T. K. Mandal et al., "Antimicrobial activity of some medicinal plants," African Journal of Traditional, Complementary and Alternative Medicines, vol. 4, no. 3, pp. 313318, 2007.

[15] B. Mahesh and S. Satish, "Antimicrobial activity of some important medicinal plant against plant and human pathogens," World Journal of Agricultural Sciences, vol. 4, pp. 839-843, 2008.

[16] R. K. Sahani and A. R. Saxena, "Fungitoxic properties of medicinal and aromatic plants against Fusarium oxysporum f.sp. pisi," Annales of Plant Protection Sciences, vol. 17, no. 1, pp. 146148, 2009.

[17] R. M. Mariita, C. K. P. O. Ogol, N. O. Oguge, and P. O. Okemo, "Methanol extract of three medicinal plants from samburu in northern kenya show significant antimycobacterial, antibacterial and antifungal properties," Research Journal of Medicinal Plant, vol. 5, no. 1, pp. 54-64, 2011.

[18] G. Hussein, H. Miyashiro, N. Nakamura et al., "Inhibitory effects of Sudanese plant extracts on HIV-1 replication and HIV1 protease," Phytotherapy Research, vol. 13, pp. 31-36, 1999.

[19] F. Mouhajir, J. B. Hudson, M. Rejdali, and G. H. N. Towers, "Multiple antiviral activities of endemic medicinal plants used by Berber peoples of Morocco," Pharmaceutical Biology, vol. 39, no. 5, pp. 364-374, 2001.

[20] V. Bhanuprakash, M. Hosamani, V. Balamurugan, R. K. Singh, and D. Swarup, "In vitro antiviral activity of Eugenia jambolana plant extract on Buffalopox virus: conventional and qPCR methods," International Journal of Tropical Medicine, vol. 2, no. 1, pp. 3-9, 2007.

[21] V. Bhanuprakash, M. Hosamani, V. Balamurugan et al., "In vitro antiviral activity of plant extracts on goatpox virus replication," Indian Journal of Experimental Biology, vol. 46, no. 2, pp. 120127, 2008.

[22] T. Kalaivani, C. Rajasekaran, K. Suthindhiran, and L. Mathew, "Free radical scavenging, cytotoxic and hemolytic activities from leaves of Acacia nilotica (L.) Wild. ex. Delile subsp. indica (Benth.) Brenan," Evidence-based Complementary and Alternative Medicine, vol. 2011, Article ID 274741, 8 pages, 2011.

[23] M. P. Raghavendra, S. Satish, and K. A. Raveesha, "In vitro evaluation of anti-bacterial spectrum and phytochemical analysis of Acacia nilotica," Journal of Agricultural Technology, vol. 2, no. 1, pp. 77-88, 2006.

[24] A. El Abbouyi, M. Toumi, Y. El Hachimi, and A. Jossang, "In vitro effects of aqueous seeds extract of Acacia cyanophylla on the opsonized zymosan-induced superoxide anions production by rat polymorphonuclear leukocytes," Journal of Ethnopharmacology, vol. 91, no. 1, pp. 159-165, 2004.

[25] R. Kukhetpitakwong, C. Hahnvajanawong, P. Homchampa, V. Leelavatcharamas, J. Satra, and W. Khunkitti, "Immunological adjuvant activities of saponin extracts from the pods of Acacia concinna," International Immunopharmacology, vol. 6, no. 11, pp. 1729-1735, 2006.

[26] W. S. Koko, M. A. Mesaik, S. Yousaf, M. Galal, and M. I. Choudhary, "In vitro immunomodulating properties of selected 
Sudanese medicinal plants," Journal of Ethnopharmacology, vol. 118 , no. 1, pp. 26-34, 2008.

[27] S. Ismail and M. Asad, "Immunomodulatory activity of Acacia catechu," Indian Journal of Physiology and Pharmacology, vol. 53, no. 1, pp. 25-33, 2009.

[28] A. Goel, D. Kumar, and A. K. Bhatia, "Modulation of immune responses by aqueous extract of Argemone maxicana leaves," Journal of Immunology and Immunopathology, vol. 10, pp. 6569, 2008.

[29] L. Stanojević, M. Stanković, V. Nikolić et al., "Antioxidant activity and total phenolic and flavonoid contents of Hieracium pilosella L. extracts," Sensors, vol. 9, no. 7, pp. 5702-5714, 2009.

[30] K. R. Brain and T. D. Turner, The Practical Evaluation of Phytopharmaceuticals, Wright Sciencetechnica, Bristol, UK, 2nd edition, 1975.

[31] W. C. Evans, Trease and Evans Pharmacognosy, WB Sauders, London, UK, 14th edition, 1996.

[32] R. Cruicshank, Medical Microbiology, Churchil Living stone, Edinburgh, UK, 11th edition, 1997.

[33] A. Kumar, A. K. Verma, A. K. Sharma, and A. Rahal, "Presence of extended spectrum $\beta$ - lactamases producing $\alpha$-haemolytic $E$. coli in Yallow-watteled lapwing (Vanellus malabaricus)," Asian Journal of Animal Sciences, vol. 7, no. 2, pp. 64-69, 2013.

[34] A. W. Bauer, W. M. Kirby, J. C. Sherris, and M. Turck, "Antibiotic susceptibility testing by a standardized single disk method," The American Journal of Clinical Pathology, vol. 45, no. 4, pp. 493496, 1966.

[35] A. Goel, Immumological studies on fileriaris [Ph.D. thesis], Central Drug Research Institute (CDRI), Lucknow, Uttar Pradesh, India, 1991.

[36] F. Denizot and R. Lang, "Rapid colorimetric assay for cell growth and survival-modifications to the tetrazolium dye procedure giving improved sensitivity and reliability," Journal of Immunological Methods, vol. 89, no. 2, pp. 271-277, 1986.

[37] Jayati, A. K. Bhatia, A. Kumar, A. Goel, S. Gupta, and A. Rahal, "In vitro antiviral potential of Ocimum sanctum leaves extract against New Castle Disease Virus of poultry," International Journal of Microbiology and Immunology Research, vol. 2, no. 7, pp. 51-55, 2013.

[38] G. W. Snedecor and W. G. Cochran, Statistical Methods, The Iowa State University, Ames, Iowa, USA, 7th edition, 1981.

[39] A. Goel, D. K. Singh, S. Kumar, and A. K. Bhatia, "Immunomodulating property of Ocimum sanctum by regulating the IL-2 production and its mRNA expression using rat's splenocytes," Asian Pacific Journal of Tropical Medicine, vol. 3, no. 1, pp. 8-12, 2010.

[40] Mahima, A. Rahal, R. Deb et al., "Immunomodulatory and therapeutic potentials of herbal, traditional/indeginous and ethnoveterinary medicines," Pakistan Journal of Biological Sciences, vol. 15, no. 16, pp. 754-774, 2012.

[41] K. Dhama, S. Mani, S. Chakraborty et al., "Herbal remedies to combat cancers in humans and animals-a review," International Journal of Current Research, vol. 5, no. 7, pp. 1908-1919, 2013.

[42] A. Kumar, A. Rahal, S. K. Dwivedi, and M. K. Gupta, "Prevalence and antibiotic profile of bacterial isolates from bovine mastitis in Mathura," Egyptian Journal of Dairy Sciences, vol. 38, no. 1, pp. 31-34, 2010.

[43] K. Dhama, R. Tiwari, S. Chakraborty et al., "Global warming and emerging infectious diseases of animals and humans:current scenario, challenges, solutions and future perspectives-a review," International Journal of Current Research, vol. 5, no. 7, pp. 1942-1958, 2013.

[44] S. Malik, A. Kumar, A. K. Verma et al., "Incidence and drug resistance pattern of collibacillosis in cattle and buffalo calves in Northwest part of Utter Pradesh in India," Journal of Animal Health and Production, vol. 1, no. 2, pp. 15-19, 2013.

[45] S. Vashney, P. Vashney, S. K. Dash et al., "Antibacterial activity of fruits of Terminelia chebula and Terminalia belerica against mastitis field isolates," Medicinal Plants, vol. 4, no. 3, pp. 167$169,2012$.

[46] K. Dhama, S. Chakraborty, A. K. Verma et al., "Fungal/Mycotic diseases of Poultry-diagnosis, treatment and control: a review," Pakistan Journal of Biological Sciences, vol. 16, no. 23, pp. 16261640, 2013.

[47] S. Satish, D. C. Mohana, M. P. Raghavendra, and K. A. Raveesha, "Antifungal activity of some plant extracts against important seed borne pathogens of Aspergillus sp.", Journal of Agricultural Technology, vol. 3, no. 1, pp. 109-119, 2007.

[48] A. Banso, "Phytochemical and antibacterial investigation of bark extracts of Acacia nilotica," Journal of Medicinal Plant Research, vol. 3, no. 2, pp. 82-85, 2009.

[49] V. Balamurugan, A. Sen, P. Saravanan et al., "Potential effect of Acacia arabica on peste des petits ruminants virus replication," Pharmaceutical Biology, vol. 46, no. 3, pp. 171-179, 2008.

[50] S. Singh, M. Taneja, and D. K. Majumdar, "Biological activities of Ocimum sanctum L. fixed oil-an overview," Indian Journal of Experimental Biology, vol. 45, no. 5, pp. 403-412, 2007.

[51] J. Kuby, Book of Immunology, W. H. Freeman and Company, New York, NY, USA, 5th edition, 2003.

[52] C. J. Liou and J. Tseng, "A Chinese herbal medicine, Fu-Ling, regulates interleukin-10 production by murine spleen cells," The American Journal of Chinese Medicine, vol. 30, no. 4, pp. 551560, 2002.

[53] A. K. Kiemer, T. Hartung, C. Huber, and A. M. Vollmar, "Phyllanthus amarus has anti-inflammatory potential by inhibition of iNOS, COX-2, and cytokines via the NF- $\kappa$ B pathway," Journal of Hepatology, vol. 38, no. 3, pp. 289-297, 2003. 

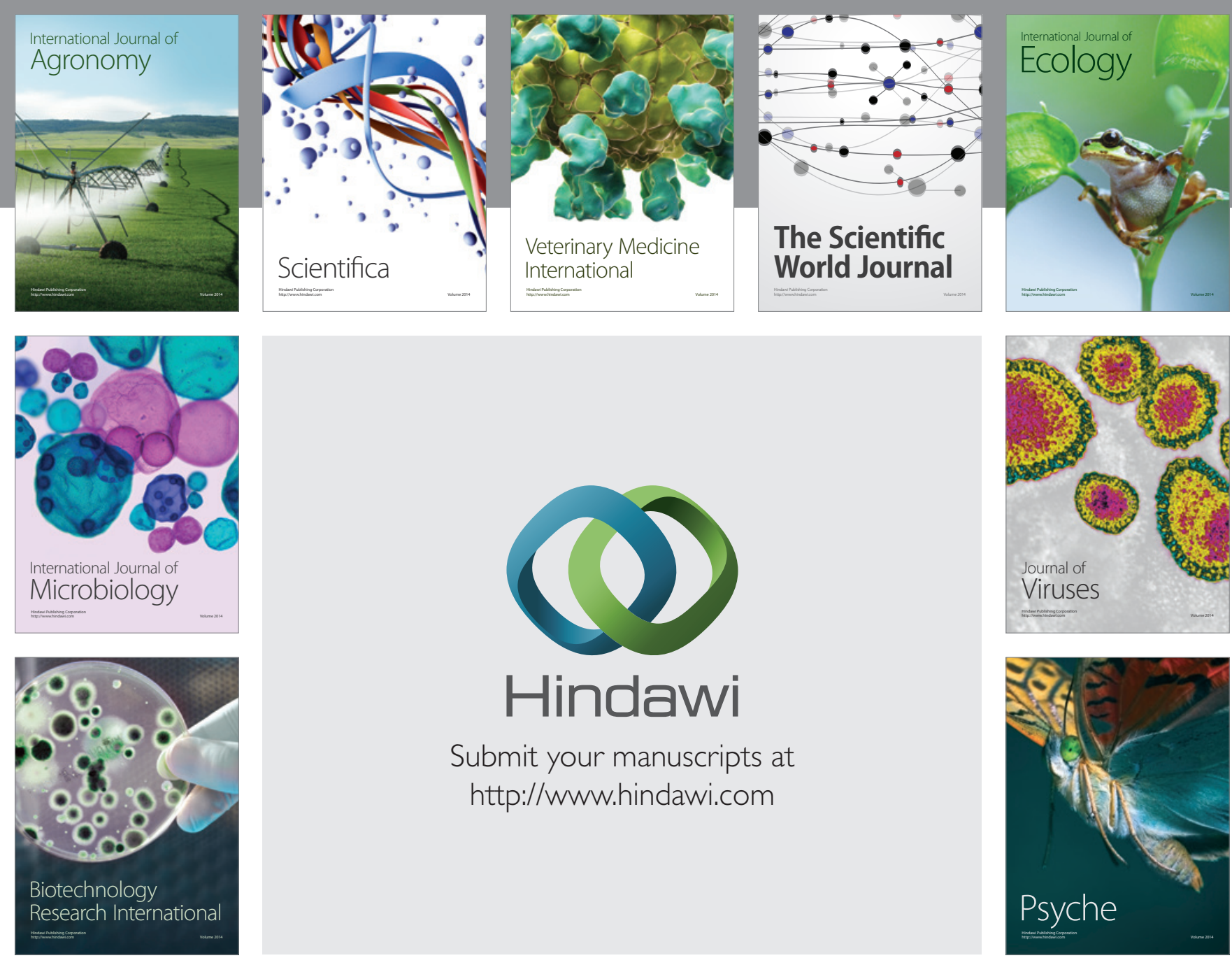

Submit your manuscripts at http://www.hindawi.com
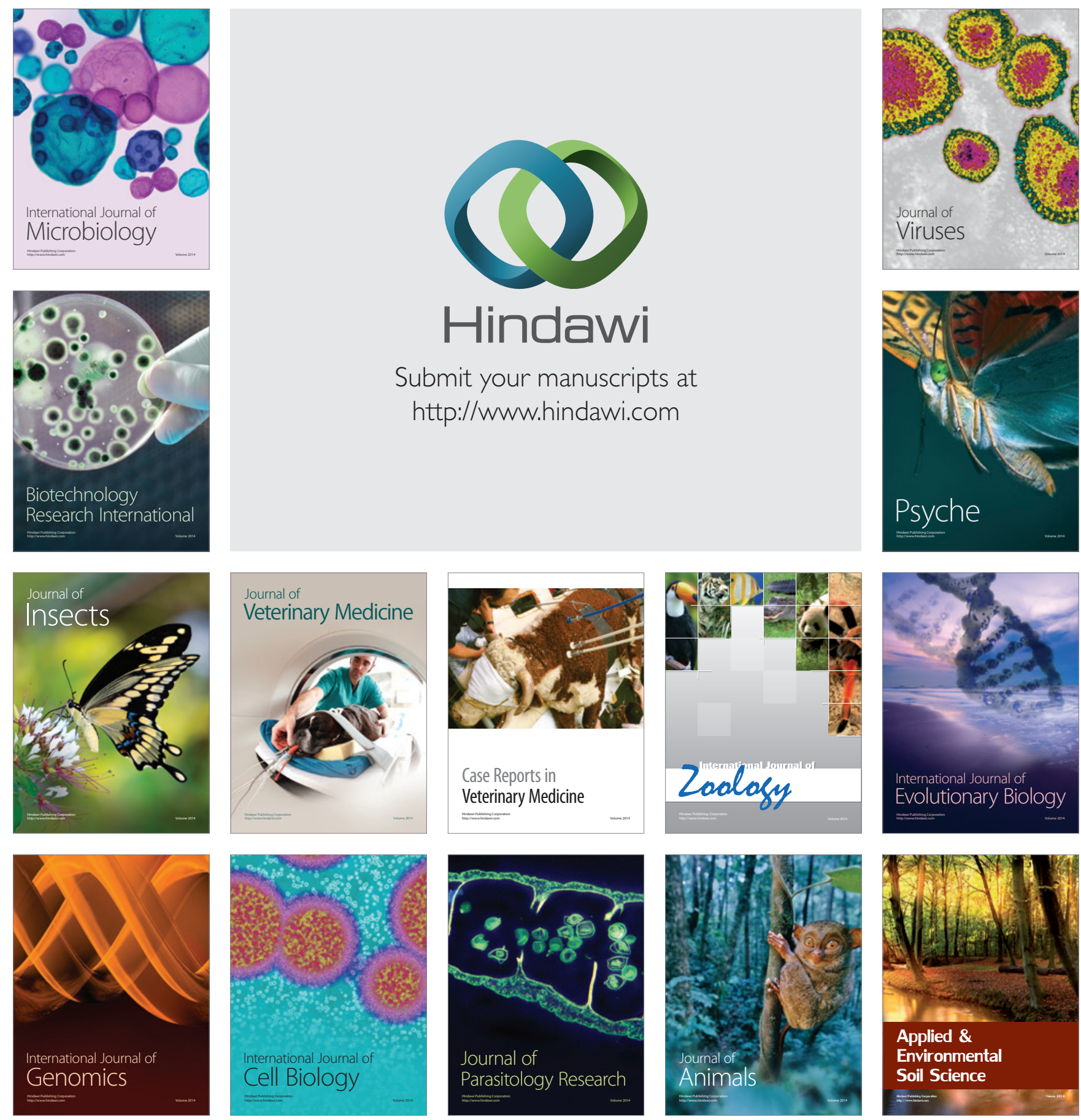